\title{
Mast Cells May Regulate The Anti-Inflammatory Activity of IL-37
}

\author{
Theoharis C. Theoharides ${ }^{1,2,3, *}$, Irene Tsilioni ${ }^{1}$ and Pio Conti ${ }^{4}$ \\ 1 Laboratory of Molecular Immunopharmacology and Drug Discovery, Department of Immunology, \\ Tufts University School of Medicine, Boston, MA 02111, USA \\ 2 Sackler School of Graduate Biomedical Sciences, Tufts University School of Medicine, Boston, \\ MA 02111, USA \\ 3 Department of Internal Medicine, Tufts University School of Medicine and Tufts Medical Center, \\ Boston, MA 02111, USA \\ 4 Immunology Division, Postgraduate Medical School, University of Chieti, 65100 Pescara, Italy \\ * Correspondence: theoharis.theoharides@tufts.edu; Tel.: +617-636-6866; Fax: +617-636-2456
}

Received: 6 June 2019; Accepted: 19 July 2019; Published: 29 July 2019

check for updates

\begin{abstract}
Mast cells are unique immune cells involved in allergic reactions, but also in immunity and inflammation. Interleukin 37 (IL-37) has emerged as an important regulatory cytokine with ability to inhibit immune and inflammatory processes. IL-37 is made primarily by macrophages upon activation of toll-like receptors (TLR) leading to generation of mature IL-37 via the action of caspase 1. In this review, we advance the premise that mast cells could regulate the anti-inflammatory activity of the IL-37 via their secretion of heparin and tryptase. Extracellular IL-37 could either dimerize in the presence of heparin and lose biological activity, or be acted upon by proteases that can generate even more biologically active IL-37 forms. Molecules that could selectively inhibit the secretion of mast cell mediators may, therefore, be used together with IL-37 as novel therapeutic agents.
\end{abstract}

Keywords: chemokines; cytokines; IL-37; inflammation; mast cells; neuropeptides

\section{Mast Cells in Inflammation}

Mast cells derive from bone marrow progenitors and mature perivascularly in all tissues [1], where they are involved in allergic reactions [2]. Mast cells also act as sensors of environmental stress [3].

In addition to allergens, mast cells are also stimulated by pathogens [4], drugs, foods, heavy metals, and "danger signals" [2], as well as certain neuropeptides including corticotropin-releasing hormone (CRH) [5], neurotensin (NT) [6] and substance P (SP) [7,8]. Both NT [9,10] and SP [11-14] are known to participate in inflammatory processes. Stimulated mast cells can secrete numerous bioactive mediators [15-17], utilizing different secretory pathways [18]. Some of these mediators are prestored in secretory granules such as histamine, tryptase and tumor necrosis factor (TNF) [19,20]; others are synthesized de novo and include leukotrienes, prostaglandins, chemokines (CCXL8, CCL2) and cytokines [20,21], that include pro- and anti-inflammatory members, [22]. Many mediators can be secreted from mast cells selectively without degranulation [23]. In particular, CRH stimulates cultured human mast cells to produce vascular endothelial growth factor (VEGF) without tryptase [5].

As a result, mast cells are not only critical for allergic reactions [2,24], but are also important in innate and acquired immunity $[25,26]$, antigen presentation $[27,28]$ and inflammation $[29,30]$. 


\section{IL-37 as An Anti-Inflammatory Agent}

The IL-1 family comprises of IL-1a, IL-1b, IL-18, IL-33, IL-36a, IL-36b, IL-36g, IL-37, and IL-38 [31]. Interleukin-37 (IL-37, formerly IL-1F7) belongs to the IL-1 family of cytokines $[7,32,33]$ and is a natural suppressor of immunity and inflammation [21,34,35].

Five isoforms (a-e) have so far been identified [34]. The " $\mathrm{b}$ " isoform of IL-37 used here is the most commonly used, but the $\mathrm{d}$ isoform was also reported to inhibit the expression of pro-inflammatory cytokines in PBMCs [36]. A specific receptor has not yet been identified for IL-37. A number of studies reported that extracellular IL-37 binds to the alpha chain of the IL-18 receptor (IL-18R $\alpha$ ) [37,38], but with much lower binding affinity than that of IL-18 [39].

Both the precursor and mature IL-37 bind IL-18R $\alpha$ [39]. In addition, IL-37 binds to an IL-18 binding protein (IL-18BP) [40], and to the decoy receptor 8 (IL-R8) [41] via which extracellular forms of IL-37 inhibit innate inflammation in vitro and in vivo [42]. Extracellularly, the IL-37 monomer is the active form involved in reducing innate immunity [43]; instead, homodimerization of IL-37 reduces its anti-inflammatory activity [44]. The precise inhibitory mechanism of action of IL-37 is presently not known. One possibility may be that it inhibits mammalian target of rapamycin (mTOR) [45] since this complex was reported to be involved in the stimulatory action of NT on human microglia [46]. Another possibility may be that IL-37 inhibits inflammasome activation as reported in murine aspergillosis [47].

There have been apparently contradicting findings of increased IL-37 in inflammatory states reported in the literature. For instance, IL-37 was reported to be increased in the brain and plasma of patients after ischemic stroke and protected them from inflammatory brain injury [48]. Other studies also showed elevated serum IL-37 concentration in patients with sepsis [49] and in ankylosing spondylitis [50]. Instead, a state of IL-37 deficiency has been reported in calcific aortic stenosis [51].

Increased gene expression of IL-37 was associated with suppression of IL-1 $\beta$ and IL-6 production from peripheral blood mononuclear cells (PBMCs) from subjects with systemic inflammatory diseases [22,50,52-55]. IL-37 has been reported to inhibit the generation of pro-inflammatory cytokines in vitro [56], as well as in vivo [57], but apparently require the IL-1 family decoy receptor IL-1R8 [58].

\section{Mast Cell-Derived Heparin and Tryptase May Regulate IL-37}

IL-37 is made primarily by macrophages in response to toll-like receptor (TLR) activation, following which, an IL-37 precursor (pro-IL-37) is cleaved by caspase-1 into mature IL-37. Some of this IL-37 enters the nucleus while the rest is released along with pro-IL-37 outside the cells [59] where both are biologically active. It was recently reported that extracellular IL-37 is active as the monomer, while binding to heparin promotes its homodimerization, with the IL-37 dimers blocking the activity of the IL-37 monomer [43]. Extracellular proteases, hypothesized to be secreted by macrophages, can process pro-IL-37 into a much more biologically active form as shown for recombinant IL-37b with the N-terminus Val46 (V46-218) [60].

Mast cells are the richest source of heparin [61] and the only source of tryptase [62] in the body. Mast cells could regulate the anti-inflammatory activity of IL-37 in different ways (Figure 1). Heparin will inhibit the action of IL-37 by promoting the creation of homodimers [43]. Moreover, heparin would stabilize the tryptase homotetramer that would promote inflammation via activation of protease-activated receptors (PAR) [63]. Instead, tryptase monomers could generate mature, superactive IL-37 [60], in a method analogous to what had been reported for IL-33 [64,65]. 


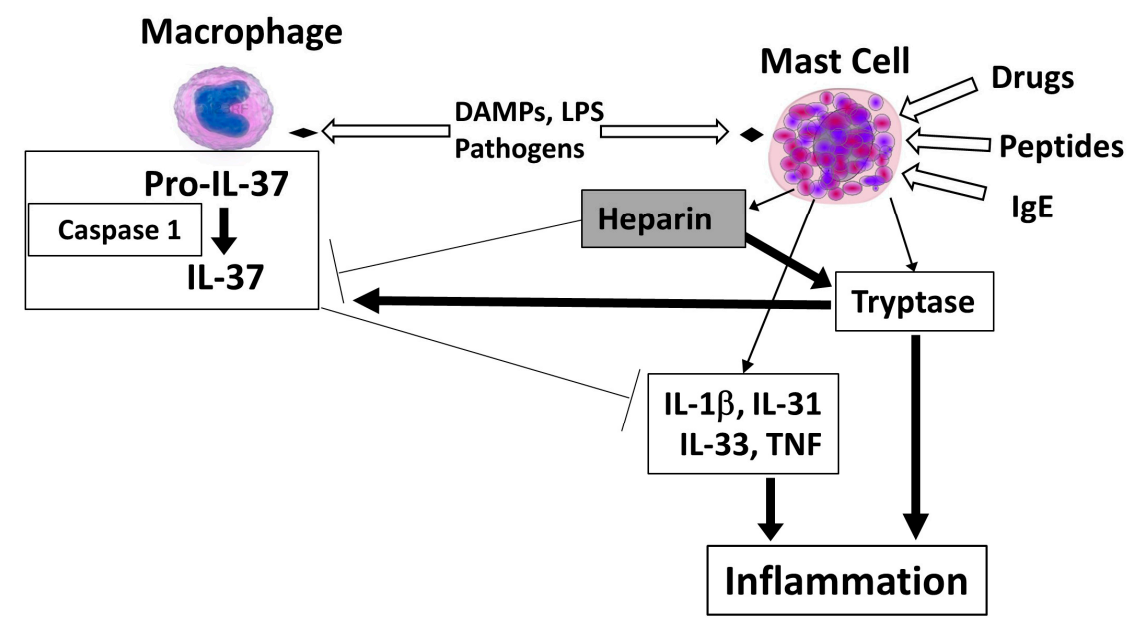

Figure 1. Diagrammatic representation of the role of mast cell-derived heparin in the regulation of the activity of IL-37. Activation of caspase 1 in macrophages, in response to TLR activation, leads to cleavage of pro-IL-37 to mature IL-37, both of which are secreted outside the cell and have anti-inflammatory activity. In the tissue microenvironment, mast cells secrete heparin, which interacts with IL-37 and promotes the formation of inactive homodimers. Mast cells also secrete the proteolytic enzyme tryptase, which exists as homotetramer bound to heparin and promotes inflammation by acting on protease-activated receptors (PAR). In the absence of heparin, biologically active tryptase monomers may be able to generate IL-37 forms with increased anti-inflammatory activity. Open arrows = activation; thin arrows $=$ secretion; thick arrows $=$ stimulation; $\mathrm{T}$ arrows $=$ inhibition.

\section{Conclusions}

We believe that the ratio of IL-1 to IL-37 is a determining factor in inflammatory diseases. Several drugs targeting IL-1 $\beta$ or its soluble IL-1R are available for treating inflammatory conditions [66], but there is still a need for more effective management of inflammation. IL-37 would be superior to other biologics beacause it is capable of inhibiting the generation of both cytokines and chemokines. IL-37 may also be administered together with other natural molecules $[67,68]$, such as the flavonoid tetramethoxyluteolin, which has been reported to inhibit mast cell release of cytokines $[8,69]$.

Funding: This research received no external funding.

Conflicts of Interest: The authors declare no conflict of interest.

\section{Abbreviations}

$\begin{array}{ll}\text { CRH } & \begin{array}{l}\text { corticotropin releasing hormone } \\ \text { chemokine }(C-X-C \text { Motif) ligand } 8 \\ \text { CXCL8 }\end{array} \\ \text { DAMPs } & \begin{array}{l}\text { interleukin } \\ \text { IL }\end{array} \\ \text { LPS } & \text { lipopolysaccharide } \\ \text { NT } & \text { neurotensin } \\ \text { PBMCs } & \text { peripheral blood-derived mononuclear cells } \\ \text { PAR } & \text { protease-activated receptors } \\ \text { SP } & \text { substance P } \\ \text { TNF } & \text { tumor necrosis factor }\end{array}$

\section{References}

1. Galli, S.J.; Borregaard, N.; Wynn, T.A. Phenotypic and functional plasticity of cells of innate immunity: Macrophages, mast cells and neutrophils. Nat. Immunol. 2011, 12, 1035-1044. [CrossRef] [PubMed]

2. Theoharides, T.C.; Valent, P.; Akin, C. Mast Cells, Mastocytosis, and Related Disorders. N. Engl. J. Med. 2015, 373, 163-172. [CrossRef] [PubMed] 
3. Theoharides, T.C. Neuroendocrinology of mast cells: Challenges and controversies. Exp. Dermatol. 2017, 26, 751-759. [CrossRef] [PubMed]

4. Franza, L.; Carusi, V.; Altamura, S.; Gasbarrini, A.; Caraffa, A.; Kritas, S.K.; Ronconi, G.; Gallenga, C.E.; Di, V.F.; Pandolfi, F. Gut microbiota and immunity in common variable immunodeficiency: Crosstalk with pro-inflammatory cytokines. J. Biol. Regul. Homeost. Agents 2019, 33, 315-319. [PubMed]

5. Cao, J.; Papadopoulou, N.; Kempuraj, D.; Boucher, W.S.; Sugimoto, K.; Cetrulo, C.L.; Theoharides, T.C. Human mast cells express corticotropin-releasing hormone (CRH) receptors and CRH leads to selective secretion of vascular endothelial growth factor. J. Immunol. 2005, 174, 7665-7675. [CrossRef] [PubMed]

6. Donelan, J.; Boucher, W.; Papadopoulou, N.; Lytinas, M.; Papaliodis, D.; Theoharides, T.C. Corticotropinreleasing hormone induces skin vascular permeability through a neurotensin-dependent process. Proc. Natl. Acad. Sci. USA 2006, 103, 7759-7764. [CrossRef] [PubMed]

7. Theoharides, T.C.; Zhang, B.; Kempuraj, D.; Tagen, M.; Vasiadi, M.; Angelidou, A.; Alysandratos, K.D.; Kalogeromitros, D.; Asadi, S.; Stavrianeas, N.; et al. IL-33 augments substance P-induced VEGF secretion from human mast cells and is increased in psoriatic skin. Proc. Natl. Acad. Sci. USA 2010, 107, 4448-4453. [CrossRef]

8. Taracanova, A.; Tsilioni, I.; Conti, P.; Norwitz, E.R.; Leeman, S.E.; Theoharides, T.C. Substance P and IL-33 administered together stimulate a marked secretion of IL-1beta from human mast cells, inhibited by methoxyluteolin. Proc. Natl. Acad. Sci. USA 2018, 115, E9381-E9390. [CrossRef]

9. Mustain, W.C.; Rychahou, P.G.; Evers, B.M. The role of neurotensin in physiologic and pathologic processes. Curr. Opin. Endocrinol. Diabetes Obes. 2011, 18, 75-82. [CrossRef]

10. Caceda, R.; Kinkead, B.; Nemeroff, C.B. Neurotensin: Role in psychiatric and neurological diseases. Peptides 2006, 27, 2385-2404. [CrossRef]

11. Mashaghi, A.; Marmalidou, A.; Tehrani, M.; Grace, P.M.; Pothoulakis, C.; Dana, R. Neuropeptide substance P and the immune response. Cell Mol. Life Sci. 2016, 73, 4249-4264. [CrossRef] [PubMed]

12. O'Connor, T.M.; O'Connell, J.; O’Brien, D.I.; Goode, T.; Bredin, C.P.; Shanahan, F. The role of substance P in inflammatory disease. J. Cell Physiol. 2004, 201, 167-180. [CrossRef] [PubMed]

13. Hokfelt, T.; Pernow, B.; Wahren, J. Substance P: A pioneer amongst neuropeptides. J. Intern. Med. 2001, 249, 27-40. [CrossRef] [PubMed]

14. Douglas, S.D.; Leeman, S.E. Neurokinin-1 receptor: Functional significance in the immune system in reference to selected infections and inflammation. Ann. N. Y. Acad. Sci. 2011, 1217, 83-95. [CrossRef] [PubMed]

15. Mukai, K.; Tsai, M.; Saito, H.; Galli, S.J. Mast cells as sources of cytokines, chemokines, and growth factors. Immunol. Rev. 2018, 282, 121-150. [CrossRef] [PubMed]

16. Theoharides, T.C.; Kalogeromitros, D. The critical role of mast cells in allergy and inflammation. Ann. N. Y. Acad. Sci. 2006, 1088, 78-99. [CrossRef] [PubMed]

17. Wernersson, S.; Pejler, G. Mast cell secretory granules: Armed for battle. Nat. Rev. Immunol. 2014, 14, 478-494. [CrossRef] [PubMed]

18. Xu, H.; Bin, N.R.; Sugita, S. Diverse exocytic pathways for mast cell mediators. Biochem. Soc. Trans. 2018, 46, 235-247. [CrossRef]

19. Gordon, J.R.; Galli, S.J. Mast cells as a source of both preformed and immunologically inducible TNF-a/cachectin. Nature 1990, 346, 274-276. [CrossRef]

20. Zhang, B.; Alysandratos, K.D.; Angelidou, A.; Asadi, S.; Sismanopoulos, N.; Delivanis, D.A.; Weng, Z.; Miniati, A.; Vasiadi, M.; Katsarou-Katsari, A.; et al. Human mast cell degranulation and preformed TNF secretion require mitochondrial translocation to exocytosis sites: Relevance to atopic dermatitis. J. Allergy Clin. Immunol. 2011, 127, 1522-1531. [CrossRef]

21. Caraffa, A.; Conti, C.; Ovidio, D.; Gallenga, C.E.; Tettamanti, L.; Mastrangelo, F.; Ronconi, G.; Kritas, S.K.; Conti, P. New concepts in neuroinflammation: Mast cells pro-inflammatory and anti-inflammatory cytokine mediators. J. Biol. Regul. Homeost. Agents 2018, 32, 449-454.

22. Gallenga, C.E.; Pandolfi, F.; Caraffa, A.; Kritas, S.K.; Ronconi, G.; Toniato, E.; Martinotti, S.; Conti, P. Interleukin-1 family cytokines and mast cells: Activation and inhibition. J. Biol. Regul. Homeost. Agents 2019, $33,1-6$.

23. Theoharides, T.C.; Kempuraj, D.; Tagen, M.; Conti, P.; Kalogeromitros, D. Differential release of mast cell mediators and the pathogenesis of inflammation. Immunol. Rev. 2007, 217, 65-78. [CrossRef] 
24. Beaven, M.A. Our perception of the mast cell from Paul Ehrlich to now. Eur. J. Immunol. 2009, 39, 11-25. [CrossRef]

25. Toniato, E.; Frydas, I.; Robuffo, I.; Ronconi, G.; Caraffa, A.; Kritas, S.K.; Conti, P. Activation and inhibition of adaptive immune response mediated by mast cells. J. Biol. Regul. Homeost. Agents 2017, 31, 543-548. [PubMed]

26. Marone, G.; Galli, S.J.; Kitamura, Y. Probing the roles of mast cells and basophils in natural and acquired immunity, physiology and disease. Trends Immunol. 2002, 23, 425-427. [CrossRef]

27. Gong, J.; Yang, N.S.; Croft, M.; Weng, I.C.; Sun, L.; Liu, F.T.; Chen, S.S. The antigen presentation function of bone marrow-derived mast cells is spatiotemporally restricted to a subset expressing high levels of cell surface FcepsilonRI and MHC II. BMC Immunol. 2010, 11, 34. [CrossRef]

28. Carroll-Portillo, A.; Cannon, J.L.; te Riet, J.; Holmes, A.; Kawakami, Y.; Kawakami, T.; Cambi, A.; Lidke, D.S. Mast cells and dendritic cells form synapses that facilitate antigen transfer for T cell activation. J. Cell Biol. 2015, 210, 851-864. [CrossRef] [PubMed]

29. Galli, S.J.; Tsai, M.; Piliponsky, A.M. The development of allergic inflammation. Nature 2008, 454, 445-454. [CrossRef]

30. Theoharides, T.C.; Alysandratos, K.D.; Angelidou, A.; Delivanis, D.A.; Sismanopoulos, N.; Zhang, B.; Asadi, S.; Vasiadi, M.; Weng, Z.; Miniati, A.; et al. Mast cells and inflammation. Biochim. Biophys. Acta 2010, 1822, 21-33. [CrossRef] [PubMed]

31. Dinarello, C.A. The IL-1 family and inflammatory diseases. Clin. Exp. Rheumatol. 2002, 20, S1-S13.

32. Vasiadi, M.; Therianou, A.; Sideri, K.; Smyrnioti, M.; Sismanopoulos, N.; Delivanis, D.A.; Asadi, S.; Katsarou-Katsari, A.; Petrakopoulou, T.; Theoharides, A.; et al. Increased serum CRH levels with decreased skin CRHR-1 gene expression in psoriasis and atopic dermatitis. J. Allergy Clin. Immunol. 2012, 129, 1410-1413. [CrossRef]

33. Konnikov, N.; Pincus, S.H.; Dinarello, C.A. Elevated plasma interleukin-1 levels in humans following ultraviolet light therapy for psoriasis. J. Invest. Dermatol. 1989, 92, 235-239. [CrossRef]

34. Dinarello, C.A.; Bufler, P. Interleukin-37. Semin. Immunol. 2013, 25, 466-468. [CrossRef]

35. Tettamanti, L.; Kritas, S.K.; Gallenga, C.E.; D’Ovidio, C.; Mastrangelo, F.; Ronconi, G.; Caraffa, A.; Toniato, E.; Conti, P. IL-33 mediates allergy through mast cell activation, Potential inhibitory effect of certain cytokines. J. Biol. Regul. Homeost. Agents 2018, 32, 1061-1065.

36. Zhao, M.; Li, Y.; Guo, C.; Wang, L.; Chu, H.; Zhu, F.; Li, Y.; Wang, X.; Wang, Q.; Zhao, W.; et al. IL-37 isoform D downregulates pro-inflammatory cytokines expression in a Smad3-dependent manner. Cell Death Dis. 2018, 9, 582. [CrossRef]

37. Pan, G.; Risser, P.; Mao, W.; Baldwin, D.T.; Zhong, A.W.; Filvaroff, E.; Yansura, D.; Lewis, L.; Eigenbrot, C.; Henzel, W.J.; et al. IL-1H, an interleukin 1-related protein that binds IL-18 receptor/IL-1Rrp. Cytokine 2001, 13, 1-7. [CrossRef]

38. Kumar, S.; Hanning, C.R.; Brigham-Burke, M.R.; Rieman, D.J.; Lehr, R.; Khandekar, S.; Kirkpatrick, R.B.; Scott, G.F.; Lee, J.C.; Lynch, F.J.; et al. Interleukin-1F7B (IL-1H4/IL-1F7) is processed by caspase-1 and mature IL-1F7B binds to the IL-18 receptor but does not induce IFN-gamma production. Cytokine 2002, 18, 61-71. [CrossRef]

39. Jia, H.; Liu, J.; Han, B. Reviews of Interleukin-37: Functions, Receptors, and Roles in Diseases. Biomed. Res. Int. 2018, 2018, 3058640. [CrossRef]

40. Bufler, P.; Azam, T.; Gamboni-Robertson, F.; Reznikov, L.L.; Kumar, S.; Dinarello, C.A.; Kim, S.H. A complex of the IL-1 homologue IL-1F7b and IL-18-binding protein reduces IL-18 activity. Proc. Natl. Acad. Sci. USA 2002, 99, 13723-13728. [CrossRef]

41. Cavalli, G.; Justice, J.N.; Boyle, K.E.; D’Alessandro, A.; Eisenmesser, E.Z.; Herrera, J.J.; Hansen, K.C.; Nemkov, T.; Stienstra, R.; Garlanda, C.; et al. Interleukin 37 reverses the metabolic cost of inflammation, increases oxidative respiration, and improves exercise tolerance. Proc. Natl. Acad. Sci. USA 2017, 114, 2313-2318. [CrossRef]

42. Dinarello, C.A.; Nold-Petry, C.; Nold, M.; Fujita, M.; Li, S.; Kim, S.; Bufler, P. Suppression of innate inflammation and immunity by interleukin-37. Eur. J. Immunol. 2016, 46, 1067-1081. [CrossRef]

43. Eisenmesser, E.Z.; Gottschlich, A.; Redzic, J.S.; Paukovich, N.; Nix, J.C.; Azam, T.; Zhang, L.; Zhao, R.; Kieft, J.S.; The, E.; et al. Interleukin-37 monomer is the active form for reducing innate immunity. Proc. Natl. Acad. Sci. USA 2019, 116, 5514-5522. [CrossRef] 
44. Ellisdon, A.M.; Nold-Petry, C.A.; D'Andrea, L.; Cho, S.X.; Lao, J.C.; Rudloff, I.; Ngo, D.; Lo, C.Y.; Soares da Costa, T.P.; Perugini, M.A.; et al. Homodimerization attenuates the anti-inflammatory activity of interleukin-37. Sci. Immunol. 2017, 2, eaaj1548. [CrossRef]

45. Li, T.T.; Zhu, D.; Mou, T.; Guo, Z.; Pu, J.L.; Chen, Q.S.; Wei, X.F.; Wu, Z.J. IL-37 induces autophagy in hepatocellular carcinoma cells by inhibiting the PI3K/AKT/mTOR pathway. Mol. Immunol. 2017, 87, 132-140. [CrossRef]

46. Patel, A.B.; Tsilioni, I.; Leeman, S.E.; Theoharides, T.C. Neurotensin stimulates sortilin and mTOR in human microglia inhibitable by methoxyluteolin, a potential therapeutic target for autism. Proc. Natl. Acad. Sci. USA 2016, 113, E7049-E7058. [CrossRef]

47. Moretti, S.; Bozza, S.; Oikonomou, V.; Renga, G.; Casagrande, A.; Iannitti, R.G.; Puccetti, M.; Garlanda, C.; Kim, S.; Li, S.; et al. IL-37 inhibits inflammasome activation and disease severity in murine aspergillosis. PLoS Pathog. 2014, 10, e1004462. [CrossRef]

48. Zhang, S.R.; Nold, M.F.; Tang, S.C.; Bui, C.B.; Nold, C.A.; Arumugam, T.V.; Drummond, G.R.; Sobey, C.G.; Kim, H.A. IL-37 increases in patients after ischemic stroke and protects from inflammatory brain injury, motor impairment and lung infection in mice. Sci. Rep. 2019, 9, 6922. [CrossRef]

49. Wang, Y.C.; Weng, G.P.; Liu, J.P.; Li, L.; Cheng, Q.H. Elevated serum IL-37 concentrations in patients with sepsis. Medicine 2019, 98, e14756. [CrossRef]

50. Chen, B.; Huang, K.; Ye, L.; Li, Y.; Zhang, J.; Zhang, J.; Fan, X.; Liu, X.; Li, L.; Sun, J.; et al. Interleukin-37 is increased in ankylosing spondylitis patients and associated with disease activity. J. Transl. Med. 2015, 13, 36. [CrossRef]

51. Zeng, Q.; Song, R.; Fullerton, D.A.; Ao, L.; Zhai, Y.; Li, S.; Ballak, D.B.; Cleveland, J.C., Jr.; Reece, T.B.; McKinsey, T.A.; et al. Interleukin-37 suppresses the osteogenic responses of human aortic valve interstitial cells in vitro and alleviates valve lesions in mice. Proc. Natl. Acad. Sci. USA 2017, 114, 1631-1636. [CrossRef]

52. Ye, L.; Ji, L.; Wen, Z.; Zhou, Y.; Hu, D.; Li, Y.; Yu, T.; Chen, B.; Zhang, J.; Ding, L.; et al. IL-37 inhibits the production of inflammatory cytokines in peripheral blood mononuclear cells of patients with systemic lupus erythematosus: Its correlation with disease activity. J. Transl. Med. 2014, 12, 69. [CrossRef]

53. Li, Y.; Wang, Z.; Yu, T.; Chen, B.; Zhang, J.; Huang, K.; Huang, Z. Increased expression of IL-37 in patients with Graves' disease and its contribution to suppression of proinflammatory cytokines production in peripheral blood mononuclear cells. PLoS ONE 2014, 9, e107183. [CrossRef]

54. Ye, L.; Jiang, B.; Deng, J.; Du, J.; Xiong, W.; Guan, Y.; Wen, Z.; Huang, K.; Huang, Z. IL-37 Alleviates Rheumatoid Arthritis by Suppressing IL-17 and IL-17-Triggering Cytokine Production and Limiting Th17 Cell Proliferation. J. Immunol. 2015, 194, 5110-5119. [CrossRef]

55. Varvara, G.; Tettamanti, L.; Gallenga, C.E.; Caraffa, A.; D’Ovidio, C.; Mastrangelo, F.; Ronconi, G.; Kritas, S.K.; Conti, P. Stimulated mast cells release inflammatory cytokines: Potential suppression and therapeutical aspects. J. Biol. Regul. Homeost. Agents 2018, 32, 1355-1360.

56. Abulkhir, A.; Samarani, S.; Amre, D.; Duval, M.; Haddad, E.; Sinnett, D.; Leclerc, J.M.; Diorio, C.; Ahmad, A. A protective role of IL-37 in cancer: A new hope for cancer patients. J. Leukoc. Biol. 2017, 101, $395-406$. [CrossRef]

57. Cavalli, G.; Koenders, M.; Kalabokis, V.; Kim, J.; Tan, A.C.; Garlanda, C.; Mantovani, A.; Dagna, L.; Joosten, L.A.; Dinarello, C.A. Treating experimental arthritis with the innate immune inhibitor interleukin-37 reduces joint and systemic inflammation. Rheumatology 2016, 55, 2220-2229. [CrossRef]

58. Li, S.; Neff, C.P.; Barber, K.; Hong, J.; Luo, Y.; Azam, T.; Palmer, B.E.; Fujita, M.; Garlanda, C.; Mantovani, A.; et al. Extracellular forms of IL-37 inhibit innate inflammation in vitro and in vivo but require the IL-1 family decoy receptor IL-1R8. Proc. Natl. Acad. Sci. USA 2015, 112, 2497-2502. [CrossRef]

59. Li, S.; mo-Aparicio, J.; Neff, C.P.; Tengesdal, I.W.; Azam, T.; Palmer, B.E.; Lopez-Vales, R.; Bufler, P.; Dinarello, C.A. Role for nuclear interleukin-37 in the suppression of innate immunity. Proc. Natl. Acad. Sci. USA 2019. [CrossRef]

60. Cavalli, G.; Dinarello, C.A. Suppression of inflammation and acquired immunity by IL-37. Immunol. Rev. 2018, 281, 179-190. [CrossRef]

61. Stevens, R.L.; Adachi, R. Protease-proteoglycan complexes of mouse and human mast cells and importance of their beta-tryptase-heparin complexes in inflammation and innate immunity. Immunol. Rev. 2007, 217, 155-167. [CrossRef] 
62. Schwartz, L.B. Tryptase, a mediator of human mast cells. J. Allergy Clin. Immunol. 1990, 86, 594-598. [CrossRef]

63. Heuberger, D.M.; Schuepbach, R.A. Protease-activated receptors (PARs): Mechanisms of action and potential therapeutic modulators in PAR-driven inflammatory diseases. Thromb. J. 2019, 17, 4. [CrossRef]

64. Lefrancais, E.; Duval, A.; Mirey, E.; Roga, S.; Espinosa, E.; Cayrol, C.; Girard, J.P. Central domain of IL-33 is cleaved by mast cell proteases for potent activation of group-2 innate lymphoid cells. Proc. Natl. Acad. Sci. USA 2014, 111, 15502-15507. [CrossRef]

65. Lefrancais, E.; Cayrol, C. Mechanisms of IL-33 processing and secretion: Differences and similarities between IL-1 family members. Eur. Cytokine Netw. 2012, 23, 120-127.

66. Dinarello, C.A.; Simon, A.; van der Meer, J.W. Treating inflammation by blocking interleukin-1 in a broad spectrum of diseases. Nat. Rev. Drug Discov. 2012, 11, 633-652. [CrossRef]

67. Theoharides, T.C.; Kavalioti, M. Stress, inflammation and natural treatments. J. Biol. Regul. Homeost. Agents 2018, 32, 1345-1347.

68. Mo, X.J.; Ye, X.Z.; Li, Y.P. Effects of euphorbia kansui on the serum levels of IL-6, TNF-alpha, NF-kappaB, sTNFR and IL-8 in patients with severe acute pancreatitis. J. Biol. Regul. Homeost. Agents 2019, 33, 469-475.

69. Patel, A.B.; Theoharides, T.C. Methoxyluteolin Inhibits Neuropeptide-stimulated Proinflammatory Mediator Release via mTOR Activation from Human Mast Cells. J. Pharmacol. Exp. Ther. 2017, 361, 462-471. [CrossRef]

(C) 2019 by the authors. Licensee MDPI, Basel, Switzerland. This article is an open access article distributed under the terms and conditions of the Creative Commons Attribution (CC BY) license (http://creativecommons.org/licenses/by/4.0/). 